\title{
Racializing Races: \\ The Racialized Groups of Interactive \\ Constructionism Do Not Undermine Social Theories of Race
}

\author{
PHILA MSIMANG \\ Stellenbosch University
}

\begin{abstract}
Adam Hochman has recently argued for comprehensive anti-realism about race against social kind theories of race. He points out that sceptics, often taken as archetypical anti-realists, may admit race in certain circumstances even if they are eliminativists about race. To be comprehensively anti-realist about races, which also means rejecting all 'race talk', he suggests that racial formation theory should be abandoned in favour of interactive constructionism. Interactive constructionism argues for the reality of racialized individuals and racialized groups to the exclusion of realism about races. Its supplementation of comprehensive anti-realism is meant to give us the ability to account for all relevant phenomena of interest surrounding the question of race without having to admit that races are real in any sense. I argue that although Hochman's interactive constructionism succeeds in establishing the existence of racialized individuals and groups, it does not do so to the exclusion of realism about social races. Furthermore, I show that his comprehensive anti-realism, even when it is supplemented with interactive constructionism, is inadequate to deal with all relevant phenomena of interest surrounding the question of race.
\end{abstract}

\section{Introduction}

Adam Hochman has recently argued for "interactive constructionism about racialized groups" as a candidate metaphysics of race (Hochman 2017; 2018). It contrasts with social and biological realism about race and is a more radical antirealism than scepticism about race. ${ }^{1}$ His interactive constructionism about racial-

1. This is because sceptics may admit of 'race' or 'race talk' under certain circumstances even if they are thoroughly eliminativists about race. The anti-realism Hochman argues for does not

Contact: Phila Msimang <MsimangP@sun.ac.za> 
ized individuals and groups rejects the purported validity of racial concepts and argues that speaking of racialized individuals and groups rather than races is the correct view and is also of a greater utility. Hochman's view goes further than ordinary forms of scepticism by being a comprehensive anti-realism about race. This comprehensive anti-realism is supplemented by interactive constructionism in order to be able to account for all the phenomena related to the individuals and groups purported to be races. According to the view, these are not members of races or race groups but, rather, they are racialized individuals and groups.

Inspiration for Hochman's conceptual framework for interactive constructionism comes from developmental systems theory (DST). DST is a biological theory in which what determines an organism's characteristics or features "is the entire matrix of resources that are needed to reproduce the life cycle" (Griffiths \& Hochman 2015:1). What reference to DST is meant to bring attention to is that talk about racialization rejects the dichotomy between biological and social factors in determining the existence of racialized individuals and groups. Rather, the argument is that racialized individuals and groups depend on a matrix of factors, including the social and biological, which are what codetermine what they are. Racialization is the term used to refer to this process in which this matrix of social and biological factors codetermines racialized individuals and groups.

The purpose of the interactive constructionist approach about racialized individuals and groups is said to be twofold: first, it is to move beyond the 'biology versus social' dichotomy in the metaphysics of race debate and, second, to provide an alternative framework to understand racial issues without having to assume that races are real in any sense. The point is to show that races are not real but also to be able to deal with racism and its attendant practices without invoking or reifying the concepts of race (Hochman 2017: 76). Hochman's aim is to replace realism about race with comprehensive anti-realism supplemented with an interactive constructionism about racialized individuals and groups that attends to both the metaphysical and normative concerns associated with race (e.g., Hochman 2017: 61-64).

make such admissions but rather aims to give us a fundamentally different ontological perspective of what we have historically called races (Hochman 2018). Hochman thus differentiates between sceptics and comprehensive anti-realists in making his case for his flavour of anti-realism. Citing major thinkers in racial scepticism, he says,

when one reads their work closely, it becomes clear that they do not reject the reality of race under all definitions of the word (Appiah 1996: 73; Corlett 2005: 571; Webster 1992: 2; Zack 2002: 106). They may be anti-realists under some or most definitions of 'race', but they are not comprehensive anti-realists. Rather, they are eliminativists about race. (Hochman 2017: 73)

In this paper I address Hochaman's comprehensive anti-realism, focusing on his 2017 formulation of it, although the arguments I make apply to comprehensive anti-realism about race more generally and also have applicability to eliminativist positions as well. What I am making is a case against anti-realism about race. 
I argue that comprehensive anti-realism, supplemented with interactive constructionism, does not achieve this: interactive constructionism and Hochman's metaphysical argument in favour of comprehensive anti-realism fail to exclude social realism about race and, thus, cannot be considered a metaphysical alternative to it. It is my purpose in this paper to show how Hochman's metaphysical and normative arguments against social kind theories of race do not succeed.

I begin by describing Hochman's motivations for comprehensive antirealism against social kind theories of race and why his proposal does not succeed (\$2). I then describe a minimalist conception of social kind theories of race that overcomes Hochman's specificity argument and responds to all the general criticisms he gave of social kind theories of race $(\$ 3)$. Having shown that social kind theories of race are not defeated by Hochman's arguments and can, in fact, be supported by interactive constructionism, I close in a short review of the arguments I have made $\left(\S_{4}\right)$.

\section{The Case for and against Comprehensive Anti-Realism}

\subsection{The Normative Argument: Against Inadvertent Promotions of Biological Realism}

Hochman argues that there is only one correct concept of race, and that this concept is the now defunct biological realism of the modern era (Hochman 2017: 72). His claim is that race "is best understood as a biological concept which fails to refer" (Hochman 2017: 63, 85). He argues that if "race is best understood as a biological concept, and one which does not refer to a natural kind, then antirealism is the right metaphysical position on the subject" (Hochman 2017: 73). He says that the reason for anti-realism's being "the least popular position in the debate about the nature and reality of race" is "because it leaves the phenomena race naturalists and social constructionists are interested in unaccounted for" (Hochman 2017: 63). His point is that

Even if we reject racial naturalism, there is still some modicum of geographically structured human biological diversity. Even if we reject social constructionism, it is still an attempt to capture something very real and important, something which cannot be reduced to categories such as ethnicity, nation, or class. (Hochman 2017: 63)

This worry is that accepting anti-realism about race would result in the omission of issues traditionally investigated under the banner of 'race research' or 'racial issues'. Hochman argues that this is something anti-realists should address both 
from an ethical and a metaphysical point of view. His solution for ensuring that anti-realists "address and illuminate these phenomena" left out by the elimination of race talk is for "anti-realism about race ... to be supplemented with realism about racialized groups" (Hochman 2017: 63). He contends that we "need to be able to talk about - and to write policy about-the groups we have been calling 'races', while at the same time avoid the metaphysical mistake of reifying race" (Hochman 2017: 63). He believes that "interactive constructionism about racialized groups allows us to do this" (Hochman 2017: 63).

Although the modern intellectual, academic, and specialist consensus is that the modern biological conception of race is false (see, e.g., Andreasen 2007; Gould 1996; James 2016; Mallon 2006; Sauer 1992; cf. Baker, Rotimi, \& Shriner 2017), responses as to what race is to mean - if race exists or doesn't exist-given these facts has differed. Contemporary biological realists have attempted to revive biological race through the use of various population concepts (Andreasen 2007; Hardimon 2017; Spencer 2017a; 2017b; 2018) and social constructionists have argued that the failure of the modern biological conception of race shows that race is a social kind (Hacking 2005; Haslanger 2012; Root 2000; cf. Mallon 2018). Sceptics such as Appiah and Zack argue that the failure of the modern biological conception of race requires us to reject race talk and be eliminativists about race (Appiah 1996; Zack 2003).

There is a certain flavour of 'constructionism' in South Africa that would be better classified as a kind of comprehensive anti-realism due its similarities to Hochman (2017) and Blum's (2002) views about race. It draws on Appiah and Zack's sceptical tradition for its eliminativism about race and draws from antirealist racialization literature (e.g., Blum 2004) for its account of social issues traditionally dealt with within racial theories (e.g., Erasmus 2012; Erwin 2012; Maré 2014). These anti-realists claim that races do not exist in any sense although race may seem to exist because of the social consequences racial concepts and their accompanying practices have had. Their claim is that the belief in race is mistaken and an illusion despite the social effects of racialization and racism (e.g., Erasmus 2012; Maré 2014; Posel 2001). In these views, only racialized individuals and racialized groups exist, and all effects of the 'illusion of race' can be explained by the racialization of individuals and the racialization of the groups to which they belong (Erasmus 2012; Posel 2001; cf. Erwin 2012). ${ }^{2}$ Hochman proposes interactive constructionism as the mechanism that constructs racialized individuals and groups. He argues that his theory of racialized individuals and groups is necessary because of what he views to be the metaphysical and normative problems faced by social kind theories of race.

2. We could call racialized individuals and groups 'RIGs'. We could also call the process of racializing individuals and groups being 'RIGed'. 
With respect to the normative problems he raises, he argues that for social kind constructionists to "defend the claim that race isn't biologically real," they "must endorse some definition of biological race and argue that the science does not support the existence of human biological races according to that definition" (Hochman 2017: 66). One way this is meant to be a problem for social constructionists is that many of them argue against 'race simpliciter'. If, Hochman argues, "almost all social constructionists talk and write about 'race' simpliciter," then, by "referring to 'race' simpliciter, social constructionists talk past [contemporary biological realists]" (Hochman 2017: 66).

In the mainstream metaphysics of race debate today, anti-realists about biological races - which include social kind theorists - deal with contemporary biological theories of race in their discussions of 'race simpliciter' (e.g., Appiah 1996; Haslanger 2012; Mallon 2006; Root 2000; see James 2016) although some social kind theorists do not (e.g., see Morning 2007). Although social theories which define biological realism only as the naturalism of the modern era cannot present themselves as exclusive metaphysical alternatives, the case of social kind constructionists who target biological realism in all its formulations are making an argument for an exclusively social kind metaphysics of race partly because they argue biological realism in all its formulations - modern and contemporary - is false or fails (Haslanger 2012: 300; Mallon 2006; Msimang 2018a).

Hochman's argument, just like social kind theories of race, rests on establishing that biological race, whatever definition of it is given, is false or fails. At the beginning of his paper, he outlines some of the reasons why biological realism about race, in all its different formulations, is taken to fail. Some of these reasons are that humans "are not a very genetically diverse species, that our biological traits are predominantly smooth in their distributions across geographic space, that there are no major human lineages, and that there is nothing scientifically privileged about conventional 'racial' classification (Hochman 2013a; Hunley, Cabana, \& Long 2015; Keita et al. 2004; Lewontin 1972; Serre \& Pääbo 2004; Templeton 2013)" (Hochman 2017: 62). Elsewhere, Hochman has arguably shown how different formulations of biological race fail and why biological realism should be seen as a failed project (e.g., Hochman 2013; 2014; 2016). I find these and other arguments against biological realism convincing (see Msimang 2018a). If Hochman is correct that there are no viable biologically realist theories of race in the contemporary debate, then the challenge that the social constructionist needs to specify each concept of race they are arguing against is no challenge at all since all the relevant formulations of race have already been dealt with and have been shown to fail. Indeed, his position itself depends on it being taken for granted that there are no viable theories of biological race left. Mainstream constructionists along with other anti-realists about biological race argue against all forms of biological realism (e.g., Hacking 2005; Haslanger 2012; Root 
2000). These constructionists present social kind theories of race as metaphysical alternatives to biological realism - not as complements to it.

Hochman denies that social kind constructionism is a metaphysical alternative that excludes biological realism. To support this claim, he points out that various arguments in the debate argue for there being both 'social races' and 'biological races'. But social kind constructionists do not need to dispute that race could be formulated as being of two complementary metaphysical kinds: one biological, which is determined by the biological sciences, and the other social, which would be determined by socio-historical factors. Notable examples of the view that there are biological and social races can be found in thinkers from the previous century such as Du Bois (1897/2015; cf. Gooding-Williams 2017), and in contemporary examples like Hardimon (2013) whom Hochman cites (2017: 66), Andreasen (2005), and Spencer (2014; 2018). These are views in which biologi$\mathrm{cal}$ and social theories of race are complementary to one another. But that such theories exist in which formulations are complementary does not preclude social kind theories which are formulated as exclusive alternatives to biological theories. The argument for social kind constructionism at the exclusion of biological realism is that given all biological facts about humans, we cannot say that there are biological races in humans. The case the social constructionist or social kind theorist is making is that we can only say that there are social races. These normative concerns Hochman expresses thus do not undermine social kind theories of race; these concerns only state what social kind theories should oppose to be an exclusive metaphysical option.

A final normative worry Hochman raises is that "race is still generally understood as a biological concept" so unless

social constructionists who are also anti-realists about biological race are able to distance 'race' from biology in the public imagination, they will give an academic stamp of approval to racial naturalism by their continued use of what has historically been a biological concept. (2017:67)

Given that social constructionists generally believe that theirs is the correct metaphysical position and that other metaphysical positions are incorrect, they argue that there is reason to discontinue biologically realist thinking about race. Moreover, given the negative social effects observed and reported of the effects of biological realism about race on the public (e.g., Condit, Parrott, Bates, Bevan, \& Achter 2004; Williams \& Eberhardt 2008) in contrast to the arguably positive social and behavioural effects of social constructionism in increasing support for social justice and reductions in racial inequalities in the public mind (e.g., 
Donovan 2016a; Williams \& Eberhardt 2008),3 constructionists argue that there are good reasons to promote social constructionist thinking to the exclusion of biological thinking about race (Donovan 2016a; 2016b; Williams \& Eberhardt 2008). So not only are there reasons against biological realism in their arguments, there is also positive reason given for social constructionism (e.g., Donovan 2016a; 2016b; Haslanger 2012).

Hochman's final worry thus stands as more of a normative or ethical prescription for social kind constructionists. What it means is that social constructionists who continue to use racial terminology must find ways to make it clear that their notion of race is not biological but is, rather, social. There is a growing literature in educational psychology that could be used to motivate this point. Empirical findings suggest that the thought that race is biological can have the effect of entrenching the belief that socio-economic and political inequalities that correlate with racial classification are natural and are as a result of biology (and so are judged to be 'fair' in some sense and do not need to be challenged), whereas social constructionist views can motivate the belief that those inequalities are of our own making through socio-political choices (and so are judged 'unfair' in some sense) with the consequence of these inequalities being seen as things that we can change through the socio-political decisions we make (Condit et al. 2004; Donovan 2016a; 2016b; Williams \& Eberhardt 2008). Furthermore, we may want to consider the evidence for the differential effects biological and cultural essentialism about race can have on support for social justice and human rights policies (Soylu Yalcinkaya et al. 2017) perhaps as a basis to argue against all essentialist formulations of race from an ethical or normative point of view.

If the "continued use of race as an analytic concept by social constructionists is likely to reinforce [biological realism] in the public imagination, even though it is the intention of most constructionists to distance 'race' from biology" (Hochman 2017: 66), this requires social constructionists to make clear to the public what they mean by their use of racial terminology. This is not a novel challenge: often the received view on an issue-say, about the purported flatness of the earth or the immutability of gender - is revised in light of a better understanding of those issues. Therefore, if social constructionism is the correct theory of race, the problem would be that the term 'race' is associated with biological theories

3. An interesting complication in this literature is the report of two recent studies by Soylu Yalcinkaya and colleagues (2017) who not only show that "endorsement of biological essentialism may have similarly negative implications for social justice policies across racial categories," they further provide evidence for "the hypothesis that endorsement of cultural essentialism would have different implications across racial categories" (Soylu Yalcinkaya et al. 2017: 1). In their discussion about how "different kinds of essentialism may have divergent implications for policies that refer to targets within (affirmative action and cultural inclusion) vs. outside (demilitarization of borders) one's society" (Soylu Yalcinkaya et al. 2017: 8), they explore some implicit risks of biological and cultural essentialism about race for policy. 
and not understood to be a social construct. Part of the normative project of such social kind theories would then have to be to correct these public misunderstandings of racial terminology (Diaz-Leon 2013; Haslanger 2000).

If Hochman's normative case for anti-realism rests on the purported benefits or detriments of particular uses of racial terminology, then, as Taylor says of Appiah's scepticism, "arguments about racial ontology should shift to the terrain of the ethical and practical, to the question of whether it is in fact more dangerous than not, more obscurantist than not, to talk of race" (Taylor 2000: 128). Although the worry that "the language used by social constructionists may inadvertently spread racial naturalism" (Hochman 2017:67) is legitimate, part of the project of social constructionism is to be prescriptive and corrective about what concepts we use and are to have (Diaz-Leon 2013; Hacking 1999: 19-20; Haslanger 2003; Mallon 2016; cf. Novaes 2018). ${ }^{4}$

If social constructionism is doomed to promote biological realism through its use of racial terminology, then social constructionism would fail at its corrective and prescriptive projects. Yet it has already been shown that education can be effective in replacing biologically realist views with those of social realism and that this can have some of the desired normative outcomes constructionists hope for (see Condit et al. 2004; Donovan 2016a; 2016b; Williams \& Eberhardt 2008). The status of the evidence for the benefits of not using race, and how this strategy performs against others, is a live debate in the literature (e.g., Blum 2004).

Excluding 'race talk' from policy is one area in which the practical consequences of eliminativism have been debated (e.g., Erasmus 2012; Msimang 2018b). In the South African debate, camps which argue for the elimination of race argue that its retention reinforces Apartheid thinking and that the use of Apartheid racial classifications leads to repeating many of the same injustices on other demographics (see Benatar 2010; Ncayiyana 2012). One argument for the retention of racial classifications in the South African context is that the elimination of racial concepts in policy, monitoring and evaluation, official statistics, and so on, amounts to a decision to disregard relevant social or demographic phenomena which are captured through the use of racial classificatory tools (Msimang 2018b; Woolard \& Woolard 2007). The social and demographic phenomena I refer to are the phenomena Hochman admits "cannot be reduced to categories such as ethnicity, nation, or class" (Hochman 2018: 63)-these are phenomena that are the result of racialization and belonging in those racialized groups (rather than other social categories - viz., these phenomena are the direct

4. Hacking (1999: 19-20) and Haslanger (2003: 303) refer to a taxonomy of prescriptive projects in which social constructionists not only identify something as a social kind but also aim to transform or eliminate it through their projects. Additionally, Haslanger argues for 'debunking projects' in social constructionism (Haslanger 2003). 
result of racial discrimination). For our purposes, whether or not races are real, it is important that we have an account of these phenomena.

It is in recognition of the problems sceptical eliminativism has in accounting for these phenomena that Hochman introduces racialized individuals and groups through interactive constructionism. Comprehensive anti-realism, unlike scepticism, is supplemented by interactive constructionism about racialized individuals and groups in order to overcome this blind spot inherent in other eliminativist views. Theories in which we cannot account for these phenomena miss much that we still want an account of and are therefore inadequate (Hochman 2017: 63; cf. Haslanger 2000). ${ }^{5}$ Seeing that his normative argument does not undermine social realism about race (but rather points out prescriptive measures constructionists should take if their positions are to be appropriate), I now turn to see if his metaphysical argument against social kind theories of race is successful.

\subsection{The Metaphysical Argument: The Case for Anti-Realism as an Alternative}

Hochman's metaphysical argument is not a positive argument for comprehensive anti-realism about race. Rather, it is a negative case against other metaphysical positions. It is an argument for why we should reject scepticism, biological realism, and social realism about race. Comprehensive anti-realism is presented as an alternative through the purported failures of these other theories. One way to summarise the logical structure of his argument is this:

1. We begin with standard social kind theories of race (they make claim to the historical emergence of race in the modern West).

2. These are undermined by historicized social kind theories of race which show that certain pre-modern groups would count as social races on a social kind approach.

3. All such social kind theories of race face the specificity problem, the specificity problem being that race becomes 'too ambiguous' in social kind theories to be analytically useful (or that social kind theories fail to specify what races are).

4. The specificity problem undermines social kind definitions of race because it shows that such races are not metaphysically well-defined: they do "not meet the standards of conceptual value" (Hochman 2017: 67).

5. The correct definition of race is the modern biological definition because it

5. If comprehensive anti-realism cannot meet this criterion, then it does not succeed. See discussion in Section 3.2. 
overcomes the specificity problem (the metaphysical position in this case is well-defined -i.e., the specification of race is the modern biological conception of race).

6. But we know that no such biological races exist (i.e., modern biological theories of race are false).

7. Therefore, races in general do not exist (since 'race' means "the modern biological conception of race" and this formulation of race is false, race in the sense of racial realism by definition is thus false).

8. For these reasons, Hochman argues that we should give up on theories of race (including social kind theories of race) and turn to comprehensive anti-realism about race.

The positive reasons Hochman supplies for comprehensive anti-realism are an argument for how comprehensive anti-realism, supplemented with interactive constructionism about racialized individuals and groups, can address all the problems metaphysicians of race are concerned about. His account is meant to be able to deal with all the relevant normative and metaphysical questions generally associated with race and racial issues (e.g., racism). In this section, I describe his metaphysical argument and how it fails to make a convincing case against social kind theories of race before moving onto showing how Hochman's interactive constructionism does not exclude social kind theories of race and, furthermore, does not deal with all the relevant normative and metaphysical questions associated with race.

\subsubsection{The Metaphysical Motivations for the Introduction of} Comprehensive Anti-Realism

Here I will reconstruct Hochman's case as a five-step argument against social kind theories of race. First, he presents the standard view of race as a social construct. This view states that race "is [a] social kind, not a biological kind," although contemporary formulations of social race have "biological inclusion criteria" (Hochman 2017: 69). This is the view that race emerges uniquely as a product of the modern West. This is a standard view in the social sciences that was taken as the consensus on the origins of race (Mallon 2013). Race was believed to be a product of the modern West, an orthodoxy that has only recently been challenged by scholars of the pre-modern (see Eliav-Feldon, Isaac, \& Ziegler 2009; Isaac 2013).

Secondly, Hochman reviews the case for the recent undermining of this standard view by scholars of the pre-modern. These scholars show that under social theories of race, modern biologization is not necessary for the establishment of racial concepts and practices. On a social kind account, the conditions sufficient for the existence of social races existed prior to the modern West (e.g., he cites 
Heng 2011a; 2011b). Hochman's review of key scholars of the pre-modern reveals that it is only by an unacceptably arbitrary decree that social kind theorists can claim that races are a modern invention that are constituted by the social with biological inclusion criteria. His point is that under social kind theories of race, races do not have to have biological inclusion criteria and that scholars of the premodern have presented numerous examples that would count as social races in recent European history (Eliav-Feldon et al. 2009; Heng 2011a; 2011b; Hochman 2017: 67-70; Isaac 2013).

Thirdly, Hochman argues that if one accepts social kind theories of race in which modern biologization is not a necessary component of the definition of race, social kind theories of race run into many counter-intuitive and purportedly unacceptable consequences. The most serious of these consequences for Hochman is that the social kind theorist would face a specificity problem. This specificity problem is that the term 'race' would become so ambiguous under social kind theories as to make some groups that we do not think of as races (such as age groups, genders, etc.) become races. The specificity problem would purportedly rob race of intellectually meaningful uses. Hochman's specificity argument, if successful, would undermine social kind theories so seriously that they would need to be abandoned. Hochman argues that the specificity argument does succeed because under social kind theories race can purportedly mean too many things. Social kind theories, he argues, make the category of race "vague and transhistorical [making it lose] its value as a conceptual resource" (2017: 68).

In the fourth step of his argument, the only way to avoid this specificity problem is to define race in terms of the modern biological conception of race. The modern idea of race is one with historical specificity and is reasonably unambiguous: the modern idea of race is the idea about human differences that arose through and was tied up in the taxonomical (and anthropological) project of classifying humans in the modern West (Hochman 2017: 69-72). This is not a social kind theory of race but is rather a biological realism about race. It is through this manoeuvre that Hochman argues that the modern biological conception of race is the correct definition of race.

In the fifth and final step of this argument, Hochman uses his metaphysical conclusion to make an eliminativist turn towards comprehensive anti-realism. Since the modern biological conception of race does not pick out any real entities-since there are no such biological races-he can safely conclude from his premises that there are no races. His argument is that if "race is best understood as a biological concept, and one which does not refer to a natural kind, then anti-realism is the right metaphysical position on the subject" (Hochman 2017: 73). The first point in this part of his argument is metaphysical: it is that there are no races. The second point in this part of the argument is normative: it is that we should eliminate races. Together, these two points provide the motivation for his 
introduction of comprehensive anti-realism about races and the introduction of racialized individuals and groups as a metaphysical and ontological alternative to all views in the contemporary philosophical debate (Hochman 2017: 67-72; cf. Hochman 2016).

\subsubsection{What's Wrong with the Metaphysical Argument}

Hochman's metaphysical argument depends on the specificity problem and the acceptance of the modern biological conception of race as the correct definition of race. Social constructionists do not have to accept either of these premises. On the specificity argument, this is because race, even though its content may have changed over time, is not as ambiguous as Hochman makes it out to be. The challenge of the specificity problem, I argue, can be met by a minimalist social kind account through its specification of what races as social kinds are. If a minimalist social kind account is successful, there would remain no reason as to why modern biological theories of race must be definitive of what races are.

Hochman anticipates such a response. With reference to the case of premodern scholars showing that social races existed before the modern era, he says:

Of course social constructionists could simply accept that race is not modern, and that it is not necessarily produced under conditions of modern biologization. They could define race . . . as a social kind distinguished on the basis of real or imagined differences, which is used to differentially distribute power and privilege between groups who have shared histories, experiences, and opportunities. This definition of race has, I think, a ring of plausibility. However, on close inspection it has extremely counterintuitive consequences. It would no longer be possible to distinguish between race and ethnicity, as race has lost its biological content. Race would be conflated with racism, as hierarchy is built into the definition of race. Worse still, men and women would count as 'races'. Men and women are differentiated on the basis of real or imagined difference, power is differentially distributed between them, and they each have shared histories, experiences, and opportunities. Even children and adults would count as different 'races' on the definition above. While we may be willing to accept that race is a vague concept, most would be unwilling to accept this variety of vagueness. (Hochman 2017: 71)

Hochman presents these examples as a reducio ad absurdum against social kind accounts of race. But they do not have the implications he suggests. Hochman has selected a very particular social kind account of race to make his argumentone which defines race as a hierarchical-social role as argued for by the likes of 
Haslanger (e.g., Haslanger 2000; 2012). But there are numerous other ways in which one could define a social race in which hierarchy need not play a necessary role. Some social kind views one could take up are institutional kind views, conferralist views, views which argue that race only exists through actions under racial description, causal effects views such as defining race in terms of geographical segregation, and so on (see Mallon 2018 and references therein). Even if Hochman's criticism succeeds against hierarchal-social views of race, it does not necessarily succeed against all social kind theories of race.

Hochman's argument only gains traction on the assumption that we accept a hierarchical-social account of race where race as "a social kind distinguished on the basis of real or imagined differences" (Hochman 2017: 71) is not restricted further by the processes, attitudes, and institutions that constitute respective types of social kinds. ${ }^{6}$ This is the basis of the specificity argument. But the specificity argument can be overcome by acknowledging that races as a kind are distinguished by the processes, attitudes, and institutions that constitute them as a social kind despite the overlap they may have with other concepts at any given point in time.

For instance, we can differentiate race and gender from one another if we recognize the difference in what constitutes them as those kinds. This is just another way to say that gender and its attendant practices such as sexism are a different social kind from race and its related practices such as racism. The secondary sexual characteristics of persons in racially stratified regimes may not be significant or necessary in the establishment of race as a social kind. But in the case of gender discrimination or sexism, secondary sexual characteristics or the sexual characteristics a person is assumed to have can be constitutive of gender as a social kind (cf. Jenkins 2018: 733-734). Hochman's argument of unacceptable ambiguity only seems plausible if we ignore the qualifications and restrictions implicit in the boundaries of human or social kinds. Hochman makes this look plausible through a very liberal interpretation of the definition he gives of hierarchal-social races; for constructionists who want to avoid this level of ambiguity, the work they would need to do is to show in what ways race is restricted and so remains meaningful. 7

6. It is worth noting that Hochman's argument for racialized individuals and groups faces the same challenge. This is because for racialized individuals and groups to be differentiable as racialized individuals and groups rather than sexualized individuals and groups, for instance, they still depend on there being qualifying constitutive factors (e.g., the processes, attitudes, and institutions or their effects) that make that social kind. I sketch what these factors are for social constructionists in §3. Hochman's own response to the specificity problem is to fall back on the definition of race as a biological kind (that does not refer), thereby specifying the meaning of race to a specific period (Hochman 2017: 77-78).

7. A 'via negativa' argument could be made in regard to specifying race as a social kind. Another strategy could be claiming that races are a classificatory scheme that shares a particular 
Instead of mounting an argument for hierarchical-social accounts of race, I will look at how a minimalist account of social kind constructionist race survives these criticisms (see \$3). I show that defining race biologically is not good historical practice, contra Hochman's argument, although it can sometimes be a convenient definition of race because of how it coincides with the beginnings of the modern racial project. There is no doubt that the racial concepts of the modern period have had a singularly significant impact on the world and how almost all peoples of the world presently relate to one another (Hacking 2005; Jackson \& Weidman 2004). Definitions of race in the modern era illuminate aspects of this process (James 2016). Nevertheless, the division between modern and pre-modern racial thinking is artificial (Eliav-Feldon et al. 2009; Isaac 2013). Moreover, ideas of races as biological or genealogical kinds are ones we can trace back to at least the ancient Greeks (Isaac 2006; Lape 2010). These theories are often more cautiously called 'proto-racist' or 'proto-racial thinking' under the assumption that fully fledged racial thinking must be underlain by modern biological theory (see Hochman 2017: 71-72 and Isaac 2006). Since racial concepts do not necessarily have to have this modern biological component, then there exists properly racial phenomena prior to modern biological formulations of race (cf. Isaac 2013; Mallon 2013).

I now turn to describing in more detail what a minimalist social kind account of race looks like and describe how interactive constructionism can be appropriated for the construction of racialised individuals and groups and race as a social kind.

\section{The Constructionisms of Race as a Social Kind}

\subsection{What Makes a Social Race?}

What makes a social race? There are numerous accounts on offer in social constructionist theories (see Mallon 2018). Underlying each of these theories is a generic view of a social race simpliciter, and it is this view of race I aim to sketch here.

Common-sense ideas of race tend to rest on the modern biological conception of race (Appiah 1996), an idea of race that we know through the contemporary scientific and intellectual consensus to be false (Andreasen 2007; Mallon 2006; cf. Spencer 2017a). Nevertheless, these groups defined by the modern biological conception of race, for socio-historical reasons, have social purchase

family resemblance in what the entities we call races end up being (cf. Ludwig 2018). Specification could also be made in terms of an explicit definition that is generalizable over what races are, as Hochman has. These options are not exhaustive. I aim not to propose any one of these methods of specification as the method of specification but suggest a way to achieve such specification in $\$ 3$. 
and are often viewed as the appropriate targets for formulating constructionist races. For instance: it does not matter that Africans and Europeans are not truly different kinds of people on a taxonomic level since this does not change the history of race-based slavery and imperial colonialism that were justified on the basis of racial ideas about such groups. The socio-political effects of these ideas have created social groups - whether they are called racialized individuals and groups after these effects or just races if racialization truly creates races. The question of if they are only racialized individuals and groups or are races is a metaphysical one whose answer has bearing on some moral questions (see \$3.2). For now, our focus is on sketching the generic features of a minimalist social kind account of race.

A social race, be it one that is defined by conceptualized practices or by the causal effects of such concepts (see Mallon 2018), shares with other social kind accounts some basic characteristics. These are the broad essentializations of a group (e.g., stereotyping); the purported inability of individuals to transition between groups in a defined social context (i.e., the fixation of immutability); the purportedly inherent genealogical heritability of group belonging (e.g., inheritance in the form of biologicization, autochthony, or a generational curse from God, etc.). Social races, as the social groups formed as a consequence of the operation and effects of racial ideas on the world, consequentially track many of the groups and features distinctive of modern biological conceptions of race although the ontology of social kinds is diametrically opposed to that of the modern biological conceptions of race (cf. Hacking 2005).

The characteristics of a social race are that they are stereotyped groups (typically identifiable by their phenotypic features and assumed ancestry), the presumption that racial identity is fixed, and the belief that race is a genealogical and heritable kind of group belonging. The modern biological conception of race carried with it the belief that these characteristics are indexical of underlying biological kind-typical characteristics. Social kind accounts do not claim that such properties exist and explain belonging in terms of socio-historical processes (with or without biological inclusion criteria) that constitute the formation of these kinds of groups.

The racial stereotype, which serves as the instrument of broad essentialization, is supposed to be a guide to the general characteristics of a racial group. Under such a view, individuals can deviate in many ways from the expected stereotype of the 'racial norm' (viz., a racial archetype) and still be considered properly a member of a given race. Of course, the stereotypical view can have the ascribed characteristics considered to be the norm of a group completely wrong: that is, on an evidential assessment, the stereotype that defines a race is incorrect. Racial stereotypes, then, can amount to mythologies about groups (whether they be biological, social, political, or otherwise). 
A race is not just a stereotyped group, it is a group that is considered to be unable to change its definitive characteristics in, say, a lifetime or generation in order to become a part of another group. A race, then, is a group that should not be able to transform or transition into another existing race group and whose individuals should not be able to transition between groups to become members of other groups. An individual born black is meant to always be black and should not, by choice or accident, be able to become another race other than that which they were born. But given the location-specificity of racial classifications and cultural cross-classification (due to race not being an objective universal biological classification but rather a social one), people can transition through travel and a shift in social norms (e.g., Ludwig 2018; Posel 2001; Piper 1992). If racial identity is seen as a judgement conferred (see Mallon 2018), a person may pass as belonging to a race that cultural or institutional rules would suggest they should not belong to. But their acceptance and integration into another race can have them and their descendants seen to be properly of the race they have become integrated into. The belonging to a race is an intersubjective fact that is fixed by the judgement conferred onto an individual, family, or group by a society (cf. Piper 1992; Posel 2001).

Racial identity is also meant to be heritable. Heritability in this sense is not necessarily biological inheritance although the concept of inheritance does include biological heritability. Race as an inherited trait or characteristic is simply one that is meant to be passed down from parents to children or from a parent to their descendants. Two illustrations may help illuminate the point. Take the modern myth about the meaning of the story of Ham (see Goldenberg 2005). The story of Ham takes place after Noah's flood where Ham and his brothers are meant to repopulate the Earth through their nuclear families. In the story, God curses the descendants of Canaan, Ham's son, to servitude to the decedents of Canaan's brothers. According to the Biblical account, God is said to have marked Ham's descendants as an indication of this curse. During America's transAtlantic slave trade, this mark of the curse put by God on Canaan's descendants was interpreted by many who were attempting to find a Biblical justification for slavery and colonialism to be black skin (Goldenberg 2005). In this narrative, race is passed down as a generational curse (and a generational blessing for Canaan's brothers' descendants). If this narrative were true, it would operate independently of whatever the facts of biology turned out to be.

Another example of inheritance which need not adhere to any biological or scientific theory is the one drop rule or some other variable versions of hypodescent. The one drop rule meant that anyone with a recent black ancestor was considered to be black. Different formulae for different calculations of racial belonging in other groups could also be constructed, but the function of these was to ascribe race by inheritance (Elliott 1999). In South African history, consistently through colonialism and Apartheid, there were definitions of race which incor- 
porated explicitly social and cultural factors in determining what race a person was to belong to despite the fact that race was seen to be an ostensibly inherited characteristic (see Posel 2001 for discussion). Race, throughout these periods, was a socio-legal construct mediated and defined by legislation (whether or not there was also a belief that these groups had some biological foundation). Racial groups were formed on the grounds of a social history of group stereotype based on their phenotypic similarities among other things; the legal definitions of these groups as races fixed the group to which individuals were to belong, and racial belonging was seen to be passed down from generation to generation.

One reason for the apparent long-term stability of racial classifications has been their selection of biological traits (e.g., skin colour and genealogy) as inclusion criteria in their definitions of race. Since biological traits do not vary arbitrarily within the lifecycle of an individual, nor do they vary arbitrarily in their offspring, and do not vary arbitrarily across generations of breeding groups, classifications using such traits would have some level of nonarbitrary consistency across individuals, families, genealogical relations, and entire groups over numerous generations. These groups can be given social significance as races whether or not races are biologically significant groupings in any biological taxonomy.

Race not being necessarily defined biologically does not, as Hochman argues, lead to a situation where it "would no longer be possible to distinguish between race and ethnicity [because] race [would have] lost its biological content" (Hochman 2017: 71). Using a hierarchical-social view of social race where race is defined "as a social kind distinguished on the basis of real or imagined differences, which is used to differentially distribute power and privilege between groups who have shared histories, experiences, and opportunities," Hochman argues that

Race would be conflated with racism, as hierarchy is built into the definition of race. Worse still, men and women would count as 'races'. Men and women are differentiated on the basis of real or imagined difference, power is differentially distributed between them, and they each have shared histories, experiences, and opportunities. Even children and adults would count as different 'races'. (Hochman 2017: 71)

As I noted above, the hierarchical-social view Hochman uses to make his point is one of many possible social kind theories of race a constructionist could use. Importantly, it does not show that a minimalist account of social race would be undermined by such criticism. Using the minimalist view of social kind formulations of race I have just described, we see that social kind accounts of race do not have to be so ambiguous as to be confounded or confused with these categories. 
Showing the importance of being able to differentiate between race and ethnicity, although the concepts may have some overlap, Hochman describes how the conception of Jewishness changed from seeing Jewish people as an ethnoreligious group in about the $13^{\text {th }}$ century to seeing Jewishness as defined in $15^{\text {th }}$ century Spain by their purity of blood doctrine (Hochman 2017: 69-71). Hochman argues that the former led to ethnic and religious persecution and only the latter led to racial persecution (contra Heng 2011b). Hochman says that this differentiation is made possible by defining race in biological terms and that social kind accounts, given his selection of a hierarchical-social role constructionist account, cannot achieve this. But under the minimalist social kind account, it is possible to differentiate between the case of Jewish people being seen as an ethno-religious group and their being seen as a race.

Given that it was seen as possible to convert in and out of the ethno-religious group before Jewish identity was 'biologized' in later centuries, the mutability and transitivity of the identity excludes it from being a racial identity. Only when the group was fixed through being biologized did it become a race. On the social kind view, there is nothing special about the biologization of this group identity. What makes it racial is that this biologization allowed for the attribution of the inherent heritability and fixation of the group identity to individuals of - and born to-that group. As we saw with the example of the story of Ham, the belief in an inherent heritability of race can operate independently of the biological facts or biological mechanisms that forms of inheritance may or may not use.

Under the minimalist account of social race, sex and gender also cannot be seen as races. There is no comparable generational consistency in sex and gender: it does not make sense under ordinary conditions to think that there is a multigenerational line of exclusively males, females, or non-binary individuals only by virtue (and because) of what sex or gender their parents belonged to. Yet this is a central assumption of the reproduction or heritability of race - the racial belonging of parents is a central factor in deciding what race their offspring is said to belong to. Age groups are also not races. In a lifetime, a person will transition between age groups - as will their parents and offspring. Individuals will never be the same age as their parents or children concurrently, yet an individual, their parents, and their children can be of the same race concurrently. Age groups are, thus, not races. Each example Hochman presents as a reducio ad absurdum for social kind accounts of race, and social kind theories more generally, does not succeed if we take a minimalist social kind view of racial constructionism.

\subsection{Social Races and Interactive Constructionism}

Ontologically, racialized individuals and groups are meant to replace races. Both are social groupings that designate the people who are generally referred to as 
races or members of a race, but the view of racialized individuals and groups denies the existence of races. Under comprehensive anti-realism, race and racialized individuals and groups are not meant to be interchangeable or synonymous. Racialized individuals and groups are supposed to be the correct ontology of the phenomena of our interest so that racialization replaces the purportedly erroneous ontology of race. It is the expressed purpose of this position "to address and illuminate these phenomena" (Hochman 2017: 63), but, as I will show with the now infamous case of Rachael Dolezal, comprehensive anti-realism supplemented with interactive constructionism fails to do this. After reviewing Hochman's argument, I favour a social kind constructionism that is compatible with positions that view racialization as the race-making process (cf. Omi \& Winant 2015).

One argument Hochman reviews that argues that racialization is a racemaking process is 'the flight to reference'. The flight to reference is an argument in which a metaphysical question (e.g., "what is race?") is decided by appeal to a theory of reference. The theory of reference would tell us what ontological entities we are to have. Using a causal-historical account of reference for racial terms, a straight-forward establishment of ontological synonymy between racialized individuals and groups and races can be made:

If the meaning of our terms "just ain't in the head", as Hilary Putnam argued, then perhaps we could be radically mistaken about what race is and still achieve reference when we talk about it (Putnam 1973). That is, when we talk about race-even when we are thinking of races as scientifically valid biological groups - we might really be talking about racialized groups. This would indeed be a consequence of Putnam's causal-historical theory of reference. If Putnam was right, maybe we can re-conceptualize 'races' as 'racialized groups' but keep on using the term 'race', despite my arguments against the category. (Hochman 2017: 76)

The problem is, this "strategy of trying to resolve metaphysical disputes by appealing to a putatively determinative theory of reference-the "flight to reference' - has . . . been discredited" because there "is no single way in which terms refer" (Hochman 2017: 76; see references therein). Thus, comprehensive anti-realism about race is immune to such lines of criticism. As a metaphysical position, racialized individuals and groups as an ontology that is exclusive of races cannot be decisively defeated by a flight to reference. I think Hochman is correct in this regard.

My argument against comprehensive anti-realism supplemented with interactive constructionism does not rest on a flight to reference. Rather, my case is built around the failures of Hochman's normative and metaphysical arguments laid out in previous sections, and the failure of racialization to disassociate itself 
from being a process of race-making. In the final analysis, I argue that interactive constructionism can serve several social kind theories of race-particularly, my minimalist account of social race. I will show how interactive constructionism can be useful to the project of constructionism and social kind theories of race.

Let us begin by looking at what Hochman says interactive constructionism is. The framework for interactive constructionism is drawn from developmental systems theory (DST). DST is "a biological framework for understanding the processes of development, inheritance and evolution (Oyama, Griffiths, \& Gray 2001; Griffiths \& Hochman 2015)" (Hochman 2017: 62). It is a theory that explains what determines an organism's traits. In the DST literature, "constructive interactionism refers to the epigenetic processes by which a variety of developmental resources interact to construct the phenotype" (Hochman 2017: 62). Hochman takes the "idea of constructive interactionism from DST" in order to "apply it to the companion concepts of 'racialization' and the 'racialized group"' but renames it "'interactive constructionism' because this phrasing highlights the fact that racialized groups are the real but contingent products of human practices" (Hochman 2017: 62).

In interactive constructionism, what makes racialized individuals and groups is the interaction of a matrix of social, political, biological, and psychological resources. This matrix of resources - the matrix of interactants-together codetermine what racialized individuals and groups are. This means that no single interactant-biological, social, or otherwise-is metaphysically privileged in the determination of racialized individuals and groups even if their contributions to the reality of racialized individuals and groups are not weighed the same.

There is a complication to this as a distinction from other metaphysical positions, as Hochman recognizes, because forms of social and biological realism already take it to be a matrix of different interactants that end up determining what races are. A social kind constructionist often depends on the clinal variation in skin colour and other phenotypic traits to be able to construct or identify social groups that are (or could be) racialized (e.g., Haslanger 2012), and some biological realists claim that biological races are the result of social forces and sexual selection that have caused or exacerbated group differences in the populations they would like to call races (see Hardimon 2013; 2017; Kitcher 1999; Spencer 2014; 2018).

Hochman's response to this point is that in the case of social and biological realism about race, the ontology of the theories decides what race a person really is. This is unlike in interactive constructionism where no one factor is given metaphysical privilege. For instance, if an individual with a high proportion of European ancestry but who also has recent African ancestry is judged to be black because of this recent African ancestry, for the social constructionist this judgement is the racialization that would make that individual truly a black person. 
Yet for a biological realist, the higher proportion of European ancestry may make it that the person in question is truly a white person despite their racialization as a black person. The metaphysical status of race in these cases is determined by either social or biological considerations: one of the two is what is given metaphysical privilege over the other. Because of the metaphysical privilege of either the biological or the social, Hochman believes that these are a "weak interactionism" and not the interactionism proper of interactive constructionism.

This response is not convincing. It is not clear that there is a meaningful distinction between weak interactionism and the interactionism 'proper' of interactive constructionism. Since Hochman argues that interactants in interactive constructionism can have varying degrees of contribution to racialization, within the process of codetermination some factors in particular contexts may have more influence than others in the racialized outcome-meaning that under codetermination there could still be deciding factors. It is consistent with this view that some of the codetermining interactants can play a larger role in some contexts and no role at all in other contexts. ${ }^{8}$ Hochman does not deny that some interactants can be more important than others in the process of racializationhe says "Interactive constructionism does not entail that biological, social, and other factors make equal causal contributions to the formation of racialized groups" (Hochman 2017: 83). Nevertheless, he avoids mention of whether these more important interactants are biological, social, or something else. This does not exclude social or biological factors being deciding interactants.

In the analogy to DST theory, DST says that neither 'nature' or 'nurture' is metaphysically privileged as it is the combined effect of all developmental factors that make the organism. Nevertheless, the organism is ontologically a biological kind despite the debate about the contribution of genetic effects (the centrally contested biological interactant) and environmental influences. In the same way, none of the interactants of racialization alone have metaphysical privilege in determining racialized individuals and groups; nevertheless, racialized individuals and groups are ontologically social kinds operational in our social world. In this metaphysics, there would be no need for there to additionally be something else called races, and racial concepts would purportedly not be interchangeable with racialized individuals and groups.

This would make it seem as if Hochman's view survives the criticism, but this is not so because what decides what level of contribution an interactant makes to

8. This will be an important point to keep in mind when considering how interactive constructionism can be used as a social kind account of race in which modern biological inclusion criteria are shown to have at one point been an important interactant in the defining of race and at other times less important and even possibly insignificant. An interesting contrast to such a view is Ludwig's (2018) account in which he argues that we should move away from discussing racial concepts in the metaphysics of race and rather focus on investigating different racial conceptions. 
a racialized individual and group is normative and socio-historical. In this way, interactive constructionism can be used to construct a social kind account of races along with a social kind account of racialized individuals and groups. Interactive constructionism does not establish racialized individuals and groups to the exclusion of races.

In terms of the DST analogy, it would be as if the environment regulated how genes and the environment contribute to the phenotype, or it would be as if biology supervised how much of a role the environment and genes would play in gene-environment interactions. This is not how DST works, but this is exactly how racialization works even within the framework of interactive constructionism. It is at this point that the analogy between DST and interactive constructionism breaks down. One of the interactants in racialization is also one of the governing factors over the role of all other interactants. The point may come across clearer when looking at Hochman's own argument for interactive constructionism in which I argue that the 'reconstruction' of racialized individuals and groups and not races does not manage to exclude social kind accounts of race.

In rejecting social kind accounts, Hochman concludes in saying that racialized individuals and groups "are not simply social constructs, they are administrative, biological, cultural, economic, geographic, gendered, historical, lingual, phenomenological, political, psychological, religious, [etc.] and social constructs" (Hochman 2017: 85). Each of the interactants he enumerates except 'the biological' and perhaps 'the geographic' are explicitly social. Non-social interactants are integrated through social selection (viz., their inclusion or exclusion is a social choice). In the list he gives, which is not presumed to be exhaustive, the only interactant that does not look to be social is the biological interactant. But the inclusion of the biological in racialization is determined by normative considerations. We know this by the fact that innumerable other combinations of biological traits - or no biological traits at all-could have been chosen as those that count for racialization. Is what becomes a part of the biological interactant of racialization skin colour, hair texture, genetic ancestry, or is it any other biological trait in which humans differ? The social is what determines what of the biological is taken to be an interactant in the matrix of factors that determines what race is. 9

Hochman positions interactive constructionism and its resultant racialization as a descriptive account rather than one with any prescriptive content. This is a problem in so far as it would not help us to answer some questions or deal with

9. Pierce's (2014) social significance view can be seen in this way. The groups which we decide to be races are normative and determined by social consideration. Social significance accounts could be viewed as a specific kind of social kind account of race where the groups we decide to be races are the populations or groups with particular traits that we choose to give social significance to despite these groups not necessarily comprising any taxonomically significant groupings. 
some theoretical and practical issues social constructionists and even biological realists would be interested in and able to answer. This would not be a problem if these questions were simply confused or misguided. One such question is the ability to determine what group a person 'really' belongs to. Hochman argues that "it does not make sense on an interactive constructionist account to ask, 'but what is she, really?"' (2017: 84) because an individual simply belongs to whatever group(s) they are racialized in and his view does not prescribe what group a person should belong to. A consequence of this account not having prescriptive content-meaning that it cannot answer questions about how persons should be classified-is that comprehensive anti-realism, even when supplemented with interactive constructionism, is an inadequate theory of the phenomena of our interest. To understand why this is a consequence of comprehensive anti-realism, we will look at the case of Rachel Dolezal. ${ }^{10}$

For all intents and purposes, before Dolezal's past was discovered the people she interacted with in her daily life thought that she was a black person. Upon discovering that her parents are white and that she had grown up a young white girl who at some point decided to take on a black persona in adulthood, she was no longer considered to be black by many of her associates and the public at large. Is she black or not? For the comprehensive anti-realist, this is not a genuine problem but is rather a confusion. Anti-realism does not answer "what is she, really?" because it is not a coherent question within its framework. The comprehensive anti-realist simply responds that Dolezal was racialized in various ways at different times by different people in different contexts: she is whatever she is racialized as, so there isn't anything that she really is beside how it is that she is racialized (cf. Hochman 2018: 6-7). There are two interconnected issues with this kind of response to the question, the one metaphysical and the other normative.

The metaphysical challenge is one regarding the social kind to which we can say she truly belongs. To answer that question requires a standard against which to measure or decide her belonging or exclusion. As I have explained above, the reason why this is not a sensible question in comprehensive anti-realism is because she would be said to belong to whatever group she is racialized as at any given time. It is not a metaphysical challenge that there is no answer to the question "what is she really?" when a person simply is whatever they are racialized as. For the comprehensive anti-realist, the metaphysical challenge may never arise.

Even so, a normative concern remains. The normative concern is a question of what must be done given her belonging or non-belonging to a particular race or racialized group. But this only arises if there is a sense in which we can say she

10. Dolezal tells her story of how she came to identify as a black person in a book about her life (Dolezal 2017). 
belongs to one or another group despite her acceptance or rejection in any particular group. It requires a standard to which we may be right or wrong about our classificatory practices in regard to an individual or a group in question.

A number of social kind theorists would say Dolezal was pretending to be a black person and not genuinely a member of the group she claimed, meaning that it was incorrect to classify her as black (e.g., as explained as an option by Diaz-Leon in Weinberg 2015). But others may argue that she was in the process of becoming black through subjecting herself to the processes of racialization that were available to her (e.g., Tuvel 2017; Weinberg 2015; cf. Mbebe 2018). I am not arguing for any answer in particular here, I am only highlighting the importance of there being an answer. My point is that anti-realism supplemented with interactive constructionism disregards a legitimate question to morally relevant concerns. ${ }^{11}$ There are moral and ethical considerations we would like to be able to make about such a case, and these rest on whether or not her assuming a black identity was legitimate. This depends on the question "but what is she, really?" having a sense in which it can be sensibly answered. It requires the possibility of 'covert racialization' in the sense of a covert social construct-a social entity whose properties can be unexpected or surprising to us in how they really are (see Mallon 2014). It requires the possibility of us being wrong or right about racialized individuals and groups or races, and thus requires that we are able to make a judgement about what a person ought to be seen as in light of the prevailing norms of classification of our day. Since comprehensive anti-realism cannot do this, it fails to fulfil its promise to attend to both the metaphysical and normative concerns associated with race. Thus comprehensive anti-realism, even when supplemented with an account of racialized individuals and groups, is an inadequate theory of the phenomena of our concern. Comprehensive anti-realism is not a successful alternative to social kind theories of race.

\section{Closing Remarks}

Hochman sets out to account for all the important issues of race without a metaphysics that affirms the existence of race. To do this he dissociates the concept of race from racialization and the construction of racialized individuals and

11. A practical question may be that of reparations. If reparations are meant to be paid to victims of racial injustice which is indexed by membership to a racialized group, would it have been fair to pay Dolezal reparations as a member of the racialized group? Or was her membership fraudulent suggesting that the hypothetical receipt of such a payment would be considered a further fraud or injustice? Without a prescriptive aspect of the theory of racialization, as social kind constructionists have, anti-realism about race leaves one incapacitated in regard to resolving these questions intellectually. 
groups. He achieves the construction of racialized individuals and groups as social groups that replace the need to talk of races through interactive constructionism (a view in which these groups are codetermined by numerous constitutive factors with none of those codetermining factors being metaphysically superior to any other). Interactive constructionism is the mechanism of racialization that results in racialized individuals and groups in his account.

Hochman argues that racialized individuals and groups are real but races are not. He argues that social kind theories of race are not viable theories of race because they run into what he calls the specificity problem. The specificity problem argues that social race is far too ambiguous to be able to specify what races are.

I have argued that the specificity problem is overcome by social kind theories given what a minimalist account of race states the determinants of race as a social kind are. Contextual factors restrict the meanings of race, resulting in an understanding of races and racialization as time and context-dependent classifications and processes. Racial classifications share general characteristics with one another that make them racial classifications rather than classifications of another kind whether or not races are argued to have biological inclusion criteria.

One of the reasons explored for why we should reject Hochman's comprehensive anti-realism supplemented with a theory of racialized individuals and groups is that it has inadequate scope over questions concerning racial issues despite the introduction of interactive constructionism being meant to deal with such issues. Through looking at the case of Rachel Dolezal, it was shown that comprehensive anti-realism, even when supplemented with interactive constructionism, is an inadequate theory of 'race' or issues associated with race. I showed how it fails to address our normative concerns through using the question of deciding Dolezal's group belonging. Since in comprehensive anti-realism a person belongs to whatever racialized group they are racialized as, there is no sense to asking what group a person ought to be racialized as. This is an important normative concern if we think misrepresentation or fraud in regard to one's belonging to a social group is possible. But in comprehensive anti-realism, we cannot say if Dolezal misrepresented herself and acted dishonestly or if her actions were legitimate and the criticism and excommunication she faced is itself unethical because the account is only descriptive and not prescriptive. Without an ability to say what a person is or is not meant to be seen as given our norms of classification, we cannot say anything that is a judgement that depends on there being a correct or incorrect form of classification in this regard. Since we cannot speak on such cases from the perspective of comprehensive anti-realism, we would have to pass over them in silence.

This normative inadequacy, in conjunction with the failure of Hochman's metaphysical arguments, fails to exclude social realism about race. Thus, com- 
prehensive anti-realism, even when it is supplemented with interactive constructionism about race, does not succeed against social kind accounts of race. I have argued that social kind theory is not defeated by anti-realism about race and that social constructionism remains the most promising account of race and its related problems.

\section{Acknowledgements}

I thank the two anonymous referees who reviewed this paper for their useful and constructive comments and I also thank Robert Mason for his meticulous proof-reading of this paper. Any remaining errors are my own. A version of this paper was delivered at the inaugural conference of the Azanian Philosophical Society at the University of Fort Hare in 2018.

\section{References}

Andreasen, Robin O. (2005). The Meaning of 'Race': Folk Conceptions and the New Biology of Race. Journal of Philosophy, 102(2), 94-106.

Andreasen, Robin O. (2007). Biological Conceptions of Race. In M. Matthen and C. Stephens (Eds.), Philosophy of Biology (455-481). Elsevier.

Appiah, Kwame A., (1996). Race, Culture, Identity: Misunderstood Connections. In K. A. Appiah and A. Guttmann (Eds.), Color Conscious: The Political Morality of Race (30105). Princeton University Press.

Baker, Jennifer L., Charles N. Rotimi, and Daniel Shriner (2017). Human Ancestry Correlates with Language and Reveals that Race Is Not an Objective Genomic Classifier. Scientific Reports, 7, 1572.

Benatar, David (2010). Just Admissions: South African Universities and the Question of Racial Preference. South African Journal of Higher Education, 24, 258-267.

Blum, Lawrence (2002). "I'm Not a Racist, but . . ." The Moral Quandary of Race. Cornell University Press.

Blum, Lawrence (2004). Systemic and Individual Racism, Racialization and Antiracist Education: A Reply to Garcia, Silliman and Levinson. Theory and Research in Education, 2(1), 49-74.

Condit, Celeste M., Roxanne L. Parrott, Benjamin R. Bates, Jennifer L. Bevan, and Paul Achter (2004). Exploration of the Impact of Messages about Genes and Race on Lay Attitudes. Clinical Genetics, 66, 402-408.

Diaz-Leon, Esa (2013). What Is Social Construction? European Journal of Philosophy, 32(4), 1137-1152.

Dolezal, Rachel (2017). In Full Color: Finding My Place in a Black and White World. BenBella Books.

Donovan, Brian M. (2016a). Learned Inequality: Racial Labels in the Biology Curriculum Can Affect the Development of Racial Prejudice. Journal of Research in Science Teaching, 54(3), 379-411. 
Donovan, Brian M. (2016b). Framing the Genetics Curriculum for Social Justice: An Experimental Exploration of How the Biology Curriculum Influences Beliefs about Racial Difference. Science Education, 10o(3), 586-616.

Du Bois, William E. B. (2015). The Conservation of Races. In N. D. Chandler (Ed.), The Problem of the Color Line at the Turn of the Twentieth Century: The Essential Early Essays (51-65). Fordham University Press. (Reprinted from The Conservation of Races, William E. B. Du Bois, 1897, American Negro Academy)

Dyer, Julie (2014). Health in Pietermaritzburg (1838-2008): A History of Urbanisation and Disease in an African City. The Natal Society Foundation.

Eliav-Feldon, Miriam, Benjamin Isaac, and Joseph Ziegler (2009). The Origins of Racism in the West. Cambridge University Press.

Elliott, Michael A. (1999). Telling the Difference: Nineteenth Century Legal Narratives of Racial Taxonomy. Law and Social Inquiry, 24(3), 611-636.

Erasmus, Zimitri (2012). Apartheid Race Categories: Daring to Question Their Continued Use. Transformation, 79, 1-11.

Erwin, Kira (2012). Race and Race Thinking: Reflections in Theory and Practice for Researchers in South Africa and Beyond. Transformations, 79, 93-113.

Gillum, Richard F., Alem Mehari, Bryan Curry, and Thomas Obisesan (2012). Racial and Geographic Variation in Coronary Heart Disease Mortality Trends. BMC Public Health, 6(12), 410.

Goldenberg, David M. (2005). The Curse of Ham: Race and Slavery in Early Judaism, Christianity, and Islam. Princeton University Press.

Gooding-Williams, Robert (2017). Du Bois. In Edward N. Zalta (Ed.), The Stanford Encyclopedia of Philosophy (Fall 2017 ed.). Retrieved from https://plato.stanford.edu/archives/fall2017/entries/dubois/

Gould, Steven J (1996). The Mismeasurement of Man (2nd ed.). WW Norton.

Griffiths, Paul E. and Adam Hochman (2015). Developmental Systems Theory. In eLS. Wiley. Retrieved from http://onlinelibrary.wiley.com/doi/10.1002/9780470015902. a0003452.pub2

Hacking, Ian (1999). The Social Construction of What? Harvard University Press.

Hacking, Ian (2005). Why Race Still Matters. Dædalus, 134(1), 102-116.

Hardimon, Michael O. (2013). Race Concepts in Medicine. Journal of Medicine and Philosophy, 38(1), 6-31. https://doi.org/10.1093/jmp/jhs059

Hardimon, Michael O. (2017). Rethinking Race The Case for Deflationary Realism. USA: Harvard University Press.

Haslanger, Sally (2000). Gender and Race: (What) Are They? (What) Do We Want Them to Be? Noûs, 34(1), 31-55.

Haslanger, Sally (2003). Social Construction: The "Debunking" Project. In F. Schmitt (Ed.), Socializing Metaphysics (301-325). Rowman \& Littlefield.

Haslanger, Sally (2012). A Social Constructionist Analysis of Race. In Resisting Reality: Social Construction and Social Critique (298-310). Oxford University Press.

Heng, Geraldine (2011a). The Invention of Race in the European Middle Ages I: Race Studies, Modernity, and the Middle Ages. Literature Compass, 8(5), 315-331.

Heng, Geraldine (2011b). The Invention of Race in the European Middle Ages II: Locations of Medieval Race. Literature Compass, 8(5), 332-350.

Hochman, Adam (2013). Against the New Racial Naturalism. The Journal of Philosophy, $110(6), 331-351$. 
Hochman, Adam (2014). Unnaturalised Racial Naturalism. Studies in History and Philosophy of Biological and Biomedical Sciences, 46, 79-87.

Hochman, Adam (2016). Race: Deflate or Pop? Studies in History and Philosophy of Biological and Biomedical Sciences, 57, 60-68.

Hochman, Adam (2017). Replacing Race: Interactive Constructionism about Racialized Groups. Ergo, 4(3), 61-92.

Hochman, Adam (2018). Racialization: a Defense of the Concept. Ethnic and Racial Studies. Advance online publication. https://doi.org/10.1080/01419870.2018.1527937

Isaac, Benjamin (2006). Proto-Racism in Graeco-Roman Antiquity. World Archaeology, $38(1), 32-47$.

Isaac, Benjamin (2013). The Invention of Racism in Classical Antiquity. Princeton University Press.

Jackson, John P. and Nadine N. Weidman (2004). Race, Racism, and Science: Social Impact and Interaction. ABC-CLIO.

James, Michael (2016). Race. In Edward N. Zalta (Ed.) The Stanford Encyclopedia of Philosophy (Spring 2016 ed.). Retrieved from http://plato.stanford.edu/archives/spr2016/ entries/race/

Jenkins, Katharine (2018). Toward an Account of Gender Identity. Ergo, 5(27), 713-744.

Kitcher, Philip (1999). Race, Ethnicity, Biology, Culture. In L. Harris (Ed.) Racism (87120). Humanity Books.

Krugell, Waldo (2014). The Spatial Persistence of Population and Wealth During Apartheid: Comparing the 1911 and 2011 Censuses. Economic History of Developing Regions, 29(2), 336-352.

Lape, Susan (2010). Race and Citizen Identity in the Classical Athenian Democracy. Cambridge University Press.

Ludwig, David (2018). How Race Travels: Relating Local and Global Ontologies of Race. Philosophical Studies. Advance online publication. https://doi.org/10.1007/s11098-0181148-x

Machery, Edouard and Luc Faucher (2005). Why Do We Think Racially? In H. Cohen and C. Lefebvre (Eds.), Handbook of Categorization in Cognitive Science (1st ed., 10101033). Elsevier.

Mallon, Ron (2006). 'Race': Normative, Not Metaphysical or Semantic. Ethics, 116(3), $525-551$.

Mallon, Ron (2013). Was Race Thinking Invented in the Modern West? Studies in History and Philosophy of Science, 44(1), 77-88.

Mallon, Ron (2014). Naturalistic Approaches to Social Construction. In Edward N. Zalta (Ed.), Stanford Encyclopedia of Philosophy (Winter 2014 ed.). Retrieved from http://plato.stanford.edu/archives/win2014/entries/social-construction-naturalistic/

Mallon, Ron (2016). The Construction of Human Kinds. Oxford University Press.

Mallon, Ron (2018). Constructing Race: Racialization, Causal Effects, or Both? Philosophical Studies, 175(5), 1039-1056.

Maré, Gerald (2014). Declassified: Moving Beyond the Dead End of Race in South Africa. Jacana Media.

Mbebe, Keolebogile (2018). Whites Cannot Be Black: A Bikoist Challenge to Professor Xolela Mangcu. Theoria, 65(1), 24-47.

Mills, Charles (1997). The Racial Contract. Cornell University Press.

Morning, Ann (2007). "Everyone Knows it's a Social Construct": Contemporary Science and the Nature of Race. Sociological Focus, 4O(4), 436-454. 
Msimang, Phila M. (2018a). Are There Any Viable Biological Theories of Race Left? (Master's thesis). University of KwaZulu-Natal. https://doi.org/10.13140/ RG.2.2.13186.99522

Msimang, Phila M. (2018b). Non-Racialism isn't in the Future of South Africa: Towards a Pessimistic View of Race. Transformations, 96(1), 72-94.

Ncayiyana, Daniel J. (2012). The Vexed Question of Race-Based Admission to Medical School. South African Medical Journal, 102(4), 193.

Novaes, Catarina D. (2018). Carnapian Explication and Ameliorative Analysis: A Systematic Comparison. Synthese. Advance online publication. https://doi.org/10.1007/ s11229-018-1732-9

Omi, Michael and Howard Winant (2015). Racial Formation in the United States (3rd ed.). Routledge.

Pierce, Jeremy (2014). A Realist Metaphysics of Race: A Context-Sensitive, Short-Term Retentionist, Long-Term Revisionist Approach. Lexington Books.

Piper, P. (1992). Passing for White, Passing for Black. Transition, 58, 4-32.

Posel, Deborah (2001). Race as Common Sense: Racial Classification in TwentiethCentury South Africa. African Studies Review, 44(2), 87-113.

Root, Michael (2000). How We Divide the World. Philosophy of Science, 67(Suppl.), S628-S639.

Sauer, Norman J. (1992). Forensic Anthropology and the Concept of Race: If Races Don't Exist, Why Are Forensic Anthropologists So Good at Identifying Them? Social Science and Medicine, 34(2), 107-111.

Searle, John R. (1995). The Construction of Social Reality. Free Press.

Searle, John R. (2010). Making the Social World: The Structure of Human Civilization. Oxford University Press.

Seekings, Jeremy (2011). Race, Class, and Inequality in the South African City. In Gary Bridge and Sophie Watson (Eds), The New Blackwell Companion to the City (532-546). Wiley-Blackwell.

Smedley, Audrey and Brian D. Smedley (2005). Race as Biology is Fiction, Race as Social Problem is Real. The American Psychologist, 6o(1), 16-26.

Soylu Yalcinkaya, Nur, Sara Estrada-Villalta, and Glenn Adams (2017). The (Biological or Cultural) Essence of Essentialism: Implications for Policy Support among Dominant and Subordinated Groups. Frontiers in Psychology, 8.

Spencer, Quayshawn (2014). A Radical Solution to the Race Problem. Philosophy of Science, 81(5), 1025-1038.

Spencer, Quayshawn (2017a). Racial Realism I: Are Biological Races Real? Philosophy Compass, 13(e12468), 1-13. https://doi.org/10.1111/phc3.12468

Spencer, Quayshawn (2017b). Racial Realism II: Are Folk Races Real? Philosophy Compass, 13(e12467), 1-16. https://doi.org/10.1111/phc3.12467

Spencer, Quayshawn (2018). A Racial Classification for Medical Genetics. Philosophical Studies, 175(5), 1013-1037. https://doi.org/10.1007/s11098-018-1072-0

Sundstrom, Ronald R. (2002). Race as a Human Kind. Philosophy \& Social Criticism, 28(1), 91-115.

Sundstrom, Ronald R. (2003). Race and Place: Social Space in the Production of Human Kinds. Philosophy and Geography, 6(1), 83-95.

Taylor, Paul C. (2000). Appiah's Uncompleted Argument: W.E.B. Du Bois and the Reality of Race. Social Theory and Practice, 26(1), 103-128. 
Tuvel, Rebecca (2017). In Defense of Transracialism. Hypatia. Advance online publication. https://doi.org/10.1111/hypa.12327

Weinberg, Justin (2015, June 15). Philosophers on Rachel Dolezal (updated). Daily Nous. Retrieved from http://dailynous.com/2015/06/15/philosophers-on-rachel-dolezal/

Williams, Mellissa J. and Jennifer L. Eberhardt (2008). Biological Conceptions of Race and the Motivation to Cross Racial Boundaries. Journal of Personality and Social Psychology, 94(6), 1033-1047.

Woolard, Ingrid and Woolard, Christopher (2007). The Social and Human Development Context. In A. Kraak and K. Press (Eds.) Human Resources Development Review 2008: Education, Employment and Skills in South Africa. HSRC Press.

Zack, Naomi (2003). Philosophy of Science and Race. Routledge. 